\title{
Methods to identify, study and understand End- user participation in HIT development
}

\author{
Anna Marie Høstgaard*, Pernille Bertelsen and Christian Nøhr
}

\begin{abstract}
Background: Experience has shown that for new health-information-technology (HIT) to be suc-cessful clinicians must obtain positive clinical benefits as a result of its implementation and joint-ownership of the decisions made during the development process. A prerequisite for achieving both success criteria is real end-user-participation. Experience has also shown that further research into developing improved methods to collect more detailed information on social groups participating in HIT development is needed in order to support, facilitate and improve real end-user participation.

Methods: A case study of an EHR planning-process in a Danish county from October 2003 until April 2006 was conducted using process-analysis. Three social groups (physicians, IT-professionals and administrators) were identified and studied in the local, present perspective. In order to understand the interactions between the three groups, the national, historic perspective was included through a literature-study. Data were collected through observations, interviews, insight gathered from documents and relevant literature.

Results: In the local, present perspective, the administrator's strategy for the EHR planning process meant that there was no clinical workload-reduction. This was seen as one of the main barriers to the physicians to achieving real influence. In the national, historic perspective, physicians and administrators have had/have different perceptions of the purpose of the patient record and they have both struggled to influence this definition. To date, the administrators have won the battle. This explains the conditions made available for the physicians' participation in this case, which led to their role being reduced to that of clinical consultants - rather than real participants.

Conclusion: In HIT-development the interests of and the balance of power between the different social groups involved are decisive in determining whether or not the end-users become real participants in the development process. Real end-user-participation is essential for the successful outcome of the process. By combining and developing existing theories and methods, this paper presents an improved method to collect more detailed information on social groups participating in HIT-development and their interaction during the development. This allows HIT management to explore new avenues during the HIT development process in order to support, facilitate and improve real end-user participation.
\end{abstract}

\section{Background}

The key objectives for healthcare services in all counties are high patient safety and high quality of treatment and care. A significant factor in achieving these objectives is an optimally functioning information and communication infrastructure, which ensures that the right information is communicated at the right time and place to the right persons. Over the past approximately 50 years,

\footnotetext{
* Correspondence: annamarie@plan.aau.dk

Department of Development and Planning, Virtual Centre of Health Informatics, Aalborg University, Fibigerstræde 13, 9220 Aalborg Ø, Denmark
}

booming healthcare and technological development has meant that the paper-based health record, which for decades has provided the infrastructure within the healthcare sector, no longer meets these requirements. Concurrent advances in information technology (IT) indicate that an electronic-based health record can resolve many of the problems associated with the paperbased health record, e.g. accessibility and data validity. This has caused many healthcare providers to make great efforts to replace the paper based-health record with an electronic record. 
Furthermore in Denmark - where the healthcare system is public and financed by taxation and the five regions ${ }^{1}$ govern the hospitals - there has been extensive discussion about the EHR in Danish hospitals. Since 1999, the Danish national strategy for IT in the healthcare sector has required that all Danish counties implement an EHR [1]. In Denmark the concept of "EHR" is defined as a platform with different modules delivered by different vendors. This means that the EHR in the five Danish regions each have their own development strategy and different platforms.

The national strategy for IT resulted in the County of North Jutland (CNJ) developing an overall IT-strategy for the EHR development process [2]. In March 2004, a local EHR working group was established with a view to producing the requirement specifications for the EHR and choosing between four possible systems.

Studies have shown that the introduction of new HIT systems - including the EHR - besides solving some problems, often brings with it a number of new problems, including some of an organizational nature [3-15]. However, research has also revealed not only pitfalls to be aware of but also success factors to be met in order for an EHR implementation to be successful [14,16-20], i.e. that the clinicians must obtain positive clinical benefits $[14,15,21]$ as a result of an EHR implementation and joint ownership [4,5,22-24] of the decisions made during the development process. A prerequisite for both is real participation in the EHR development process enabling clinician's to exert real influence in decision-making [4,5,16,22,24-27]. Mumford classifies user-participation in IT-development in three different types according to depth: consultative, representative and consensus participation [28,29]. According to Mumford real influence not pretended or symbolic - in HIT-development is best achieved by using the consensus type of participation, where the users are involved throughout the technological development process [28,29].

Prerequisites for real participation/influence are as follows.

- Early involvement of clinicians (end-users) in HIT development is essential because, as the technological development process proceeds, the scope of influence of the clinicians and the possibility of changing the decisions already made are progressively limited [22,23,30-32].

- The best possible representation of all groups of clinicians in order to achieve joint ownership from all relevant actor-groups [25,28,33]).

- The possibility of workload reduction - meaning that colleagues take over part/all of the clinical duties for the clinicians involved (it does not involve extra payment) $[22,26]$.
When it comes to achieving a successful implementation of the EHR, all groups of clinicians are important user participation groups in the development process. However, more studies show that physicians are a very important group because their acceptance is crucial as to whether or not the EHR is implemented in the intended way [34-36].

Based on a literature review and the results of an AMIA workshop, Kaplan et al. [17] report that many HIT systems are not successful "despite an accumulation of best practices research identifying success factors". Kaplan et al. therefore call for further research into the development of improved methods for successful HIT development. Even though user involvement/user participation is known to be a very important success factor, no empirical studies of user involvement in the health information field have been conducted in recent years, whereas a number of studies of user involvement have been completed in the medical device field [37-41].

In this perspective, an improved method for collecting more detailed information on end-user participation in HIT development in order to support, facilitate and improve real end-user participation was developed throughout a research study of the EHR planning process in the County of North Jutland (CNJ) focusing specifically on physicians as a relevant social group in EHR development. Besides the physicians, IT-professionals and administrators were identified as significant groups based on prior research and own experiences [14,35,36,42].

The objective of the research was to develop an improved method for identifying, studying and understanding end-user participation in HIT development in order to collect more detailed information on social groups participating in HIT development and their interaction during the development. This allows HIT management to explore new avenues during the HIT development process in order to support, facilitate and improve real end-user participation.

The objective was achieved by answering the following two research questions:

1. Did the physicians have the necessary resources (interest, power, organization, information, access and knowledge) during the EHR planning process to change their status from potential to actual social carriers $^{2}$ of the EHR-technology?

2. Can the answer to the first research question be understood by studying the different "meanings" 3 that each of the relevant social groups, (physicians, IT-professionals and administrators), attached/ attaches to the EHR?

An improved method to collect more detailed information on social groups participating in HIT 
development and their interaction during the development will fill a void in the current body of knowledge about success factors and best practices and, not least of all, on how to apply these in practice.

\section{Theoretical framework}

The new methodological approach is based on the combination and further development of the following two theories:

- the Socio-Technical-Carrier-of-Technology theory (STCT)

- the Social Construction of Technology theory (SCOT).

The STCT theory was developed by researchers at Aalborg University in the 1990s by combining and further developing two theories: the Socio-Technical theory and the Social-Carrier-of-Technology theory.

\section{The Socio-Technical theory}

In the Socio-Technical theory a broad concept of technology is introduced, focusing on the micro-level and the actor as opposed to the macro-level. This technology concept is open-ended to enable an understanding of the relation between technological and social change. According to the concept, technology embraces a combination of four constituents: technique (meaning the technological object in question), knowledge, organization and product. These four constituents are inseparable components of any technology. A qualitative change in any one of the components will eventually result in supplementary, compensatory, and/or retaliatory change in the other components. For a technology to be considered as such, it has to be applied and result in a product, and for this to happen, actors have to be active within each of the four components.

The Socio-Technical theory is process-oriented and focuses on the technological de-velopment process. It can be described in five stages. Within each of these stages, the actors make their selections based on possibilities and interests. This means that at every stage a selection takes place which leaves out many potential actions not chosen (Figure 1) [43-45].

\section{The Social-Carrier-of-Technology theory}

The focus of the Social-Carrier-of-Technology theory is the actors. It was developed to identify and study the relevant "Social-Carriers-of-Technology" involved in the development of new technology ${ }^{4}$. The concept refers to a group of actors, or a social entity, who choose the new technology and carry it forward towards the next phase in a technological development process. According to this theory, this will happen only if the "Social-

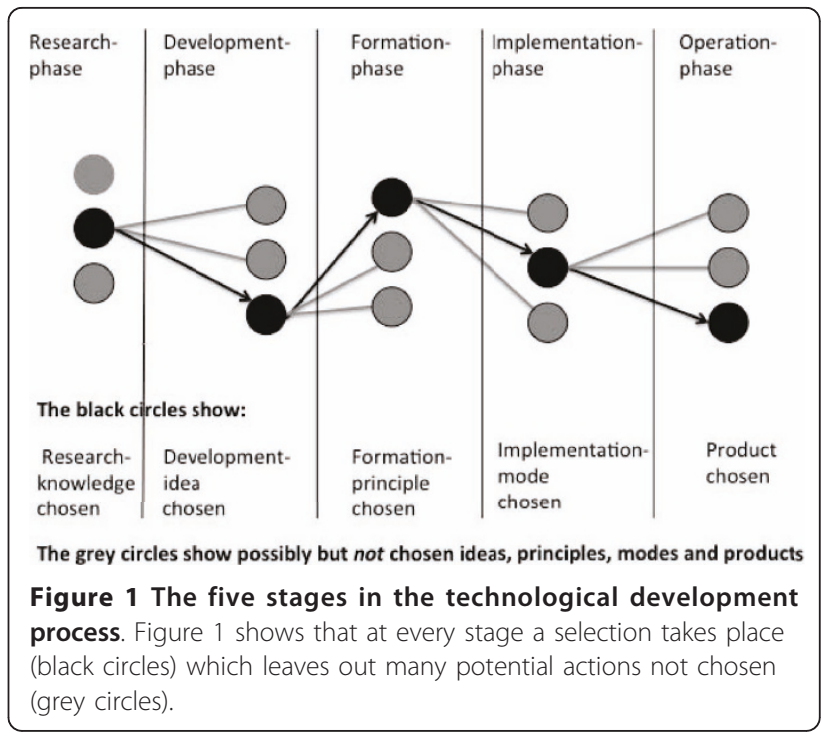

Carriers-of-Technology" have the necessary resources (interest, power, organization, information, access and knowledge) to change their status from potential to actual carriers of the technology in question. Often two or more Social-Carrier-of-Technology groups choose and implement the technology together. These groups are named combined Social-carriers-of-Technology. When, on the other hand, the social groups involved carry the technology in different phases of the development process and, in this way, are sequentially linked to each other, they are named linked Social-Carriers-ofTechnology. In reality the combined and linked SocialCarriers-of-Technology are most often intertwined [46].

\section{The Socio-Technical-Carrier-of-Technology theory (STCT)}

The theory developed by combining the Socio-Technical theory and Social-Carrier-of-Technology theory is termed: the Socio-Technical-Carrier-of-Technology theory (STCT) $[26,43,47,48]$. According to this theory, the choices made by the actors include not only the technique but all four components in the socio-technological technology concept: technique, knowledge, organization and product. The STCT theory states that every qualitative change - and the final outcome/product - in a technological development process can be traced back to a change in the composition of the social carriers of technology and in the conditions necessary to achieve the status of an actual Social-Carrier-of-Technology.

With a focus on physicians, the different social groups' participation in the EHR planning process and their influence in decision-making were studied by examining:

- the vested interests of the different relevant social carrier groups of technology in relation to the EHR (interest); 
- their options to carry through these interests (power);

- the degree of support from their professional association (organization);

- their opportunities to see and test the system in practice (access); and

- the amount of knowledge and information they had acquired about EHR both in general and particularly regarding the different options available (knowledge and information)

In the present study the STCT theory was used as a framework to shed light on the interactions that occurred between the different relevant social groups in the local, present perspective - i.e. within a relatively short time frame.

\section{The Social Construction of Technology theory (SCOT)}

According to the SCOT theory, every stage in a technological development process involves choices between various options. These choices are made by the different social groups involved based on the different "meaning ${ }^{45}$ they attach to the technological object in question. This means that the design and the further development of the technological object is as a result of gradual and mutual debates between the different social groups, and that besides rather narrow, purely professional considerations, social factors (interests, power) determine which options are chosen. This results in a "multidirectional" development model in contrast to the linear model often described in the history of technology [49].

During the technological development process different problems will appear as a result of the different "meaning" each social group attach to the technological object. These problems are resolved through negotiations between the groups - the final solution being highly dependent on the interests and the amount of power of each group involved [49].

The various social groups operate from different "technological frames". A technological frame represents e.g. the purposes, the goals and the problem-solving processes attached to the technological object - historically and nowadays - for the different social groups. The contents of this frame determine which "meaning" a particular social group attaches to the technological object, and it also structures the interaction between the actors within each group [49].

According to the SCOT theory, studies of a technological development process must start out by identifying the relevant social groups. It is obvious that the endusers represent a relevant social group, but also less obvious social groups must be identified. Once the relevant social groups are identified, the next step is to identify the different problems that each social group attach to the technological object. For each problem it is then possible to identify a range of solutions from the social groups involved. This way of describing the development process clearly shows the interpretive flexibility of the technological object and of its future functionality. It also clearly demonstrate that during a technological development process a number of conflicts will arise: different social groups express various technical needs, numerous solutions to a problem, moral conflicts, etc. [49].

In the present study the SCOT theory provided a framework for understanding the underlying reasons for the different social groups' vested interests in the health record and the power they had or did not have to bring forward those interests. The historical perspective was, therefore, included in an attempt to uncover the "meaning" that has been attributed by the different relevant social groups to the health record from its origins in a paper format to the electronic format of today - and in order to gain an understanding of the historical and current interests and the balance of power between the social groups.

The STST and the SCOT theories are both wellknown. What is new is the act of combining them and employing them within the healthcare sector, which has not been done previously.

\section{Methods}

\section{Design}

In accordance with the two research questions the research project was divided into two parts: a case study and a literature study.

\section{Case study}

The three Social-Carrier-of-Technology-groups (the STCT theory) were studied in the local, present perspective with a focus on process-orientated technology analysis. They consisted of physicians and IT-professionals in the EHR working group and the ICT-board of the CNJ. The context was the EHR planning process in the $\mathrm{CNJ}$ in Denmark, and the research period lasted from October 2003 until April 2006.

\section{Literature study}

In the literature study the three relevant social groups (the SCOT theory) were studied in the national, historic perspective. They consisted of physicians and IT-professionals associated with the Danish hospital sector and hospital managers and EHR decision-makers at county/ regional level.

\section{Data collection and analysis}

Data in the case study (the local, present perspective) were collected as presented in Table 1. 
Table 1 Data collection in the case study

\begin{tabular}{|c|c|}
\hline $\begin{array}{l}\text { Data collection } \\
\text { techniques }\end{array}$ & Techniques used for this study \\
\hline Interviews & $\begin{array}{l}\text { Semi structured interviews with } 11 \text { physicians (including all physicians in the EHR working group), } 2 \text { IT-professionals, } 2 \\
\text { Administrators. The interviews, lasting from } 60 \text { min., were recorded and transcribed. }\end{array}$ \\
\hline Observations & Participant observation at EHR working group members \\
\hline $\begin{array}{l}\text { Insight into } \\
\text { documents }\end{array}$ & Minutes from meetings, project plans, tender material etc. \\
\hline Validation of data & Data-triangulation, transcripts sent to interview-persons, written report sent to participants \\
\hline
\end{tabular}

Data were analysed using a Socio-Technical "technology-carrier analysis" developed by researchers at Aalborg University $[30,43,47]$. The software programme ATLAS [50] was used to analyse interviews. The focus was on the six conditions required to achieve the status of an actual social carrier of EHR (interest, power, organization, information, access and knowledge) and an "open mind" towards other themes.

A new framework of visualizing the results of the technology-carrier analysis was developed (table 2). A number of marks were given to indicate whether the conditions to become an actual social carrier of the EHR were met for the different social groups involved.

Three marks ( $\mathrm{g} \mathrm{g} \mathrm{\Xi})$ indicate that the group achieved the status of an accrual social carrier of EHR. Two marks $(\mathrm{g} \mathrm{g})$ indicate that the group was a very potential social carrier - and one ( $₫$ ) indicates that the group was a less potential carrier. It is important to stress that the table only serves as a visualization of the results; the number of marks given are based on the researchers thorough qualitative analy-sis of each of the six conditions involved.

In the literature study, data were collected through searches in PubMed and Google Scholar. The research strategy was as follows:

- the history and the development of the Danish health record - paper based as well as electronic based

- the history of the Danish physicians, their interest in the health record and the way in which they were/are organized

- the history of the Danish IT-professionals and the Danish administrators, their respective interests in the health record and the way in which they were/ are organized
Also relevant textbooks were used within the above areas [51-53].

Data were analysed using SCOT analysis [49,54]. The analysis included:

- identifying the technological object and the relevant social groups and

- studying the different meaning that these groups attach to the technological object and their respective technological frames.

\section{Ethical approvals}

According to Danish law ("Law on the Scientific Committee System and the treatment of biomedical research, chapter 3, section 3"), formal approval from "The Danish National Committee on Research Ethics" was not required. Concerning the individual participants (physicians, IT-professionals and administrators) informed consent was obtained prior to data collection.

\section{Results}

Technology-carrier analysis

The planning strategy: factors affecting all six conditions

Some factors related to the planning strategy affected all six conditions. They are reported in this section.

An EHR working group was established by the ICTboard to draw up requirement specifications and to choose between four EHR systems. The members of the working group comprised physicians, nurses, secretaries and IT-professionals. Two out of eight physicians in the EHR working group were members from the start. The other six joined the group 18 months later.

The - predominantly informal - planning strategy for the EHR planning process meant that there was no clinical workload reduction at all during the process.

Table 2 Framework for visualization the technology-carrier analysis

\begin{tabular}{llllll}
\hline Social group $\quad$ Interest & Power & Organization & Information & Access & Knowledge \\
\hline Physicians & & & & \\
\hline IT-professionals & & & \\
\hline IT-board
\end{tabular}

The results of the analysis will be added in the tablebody. 
Physicians were expected to handle their full-time clinical duties, while at the same time participating in the planning process. They were expected to read a vast number of ICT - technical papers and reports. Consequently, seven out of eight physicians in the workinggroup were senior physicians from Aalborg Hospital (the main hospital in the $\mathrm{CNJ}$ ) who to some extend mastered their clinical tasks. Only one junior physician from a hospital outside Aalborg - joined the group. He participated in two meetings whereupon he had to leave the group due to lack of time. It meant that junior physicians (more than half of the physicians in the CNJ) and physicians from hospitals outside Aalborg were not represented in the "EHR Working Group".

During the planning process the EHR-project management made no attempts to learn from the experiences of management of EHR planning-processes in the other Danish counties - including experiences about the need for workload reductions in one form or another. The EHR-project management's main argument for not allowing workload reduction (paid by the county) was a general principle about leaving decisions about workload reduction to the individual hospitals in the county. From the ICT-board' point of view, the local hospital's incentive to pay for workload reduction was the fact that the individual hospitals were allowed to keep any rationalization gains from the EHR implementation process themselves. This principle meant that the responsibility for prioritizing costs for workload reduction e.g. treatment and care, was moved from county-level to hospital-level. Based on experiences regarding the prerequisites for a successful implementation of EHR, a decision like this should be made at county-level to ensure the best possible implementation across the county. The fact that no sharing of past experiences at any level (strategic, tactical and operational) took place before or during the EHR planning process could indicate that the EHR-project management had underestimated the workload associated with the planning process.

\section{Interest}

The three technology-carrier groups had different interests in the implementation of the EHR. The physicians' main interest was to ensure positive clinical benefits. To achieve this, physicians found it important that it was physicians, who formulated the medical demands in the requirement specification. The IT-professionals' main interests were concerned with optimizing administrative functions in the EHR, while the ICT-boards had a major interest in complying with the national requirements about implementing EHR in all Danish counties.

A new way of implementing the planning process was used in the CNJ: a "dialogue based planning-process". It facilitated dialogue between the members of the working group and the four vendors possible, and it made it possibly for each of the vendors to change system functions - e.g. the configuration of the user-interface - during the process. The physicians felt that this enabled them to gain some insight into more aspects of the systems and to argue for their clinical demands and interests in the EHR. However, the physicians did not have sufficient time (no workload reduction) to go through all documents related to the process. Neither did they have the time to participate in all meetings in the "EHR Working Group" or meetings and workshops in the sub-groups established in relation to the process. As a consequence, IT-professionals with past clinical background (non-physicians) developed most of the medical demands in the requirement specifications. This implies according to Kensing et al. [25], Brandt [55] and Simonsen et al. [56] a great risk; namely that the medical requirements do not reflect the clinical reality, because experience shows that professional knowledge has to be presented by the professionals. At the same time, it implies a great risk in that the physicians' interests were not, or only partially, met during the process.

All four EHR systems were at a very early developmental stage at the time of the planning process. None of them were in operation in any hospital ward - they only existed as the vendors schematic diagrams and early prototypes. This fact taken together with the fact that all the vendors changed the system functions related to clinical work practices (e.g. configuration of the user interface, the number of mouse clicks and integration with other systems) during the development process, resulted in the four systems becoming almost alike. Therefore clinical related functions were abandoned as criteria for selection of the EHR system. Now only technical differences were used to choose between the systems. Thus, the physicians made their choice according to feelings, sensations - and advice from the IT-professionals. Thus, the final choice of EHR system was primarily made on the basis of the interests of the IT-professionals and the ICT-board, i.e. according to technical and economic criteria.

\section{Power and organization}

The Danish Medical Association was not involved in the planning process in any way. The organizational support and encouragement that the physicians in the working group achieved during the planning process came from colleagues at Aalborg Hospital.

Compared to the physicians, the IT-professionals had much more organizational support - and power. The fact, that their organization was in charge of the project management and - compared to the physicians - they were well represented in both the ICT-board and all other groups related to the process - and that most of the documents prepared during the EHR process were prepared by members of their organization - gave them a significant amount of power. 
The director of IT-Health was also the EHR-project manager. At the same time, the director and two heads of department at "IT-Health" were members of both the ICT-board and the EHR Steering Group. Thus, the ITprofessionals were part of the decision-making authority (Figure 2).

The physicians and the IT-professionals also used the power associated with profes-sional knowledge to accommodate their own respective interests. However, the physicians' clinical knowledge turned out to be inadequate as a basis for choosing between systems. Technical knowledge was essential.

The ICT-board had the power to make final decisions - which they did, when they ordered all physicians to choose one of the systems despite the physicians' request to wait until more useful information, access and knowledge were available. In fact, the physicians were powerless when it came to the possibility of being able to exert real influence on which system to choose.

Access

The four systems selected were not in operation in any hospital ward and therefore, it was not possible to test them in a "real live setting". This was critical, especially to the physicians as they were asked to specifically concentrate on the system functions related to clinical work practices (e.g. configuration of the user interface, the number of mouse clicks and integration with other

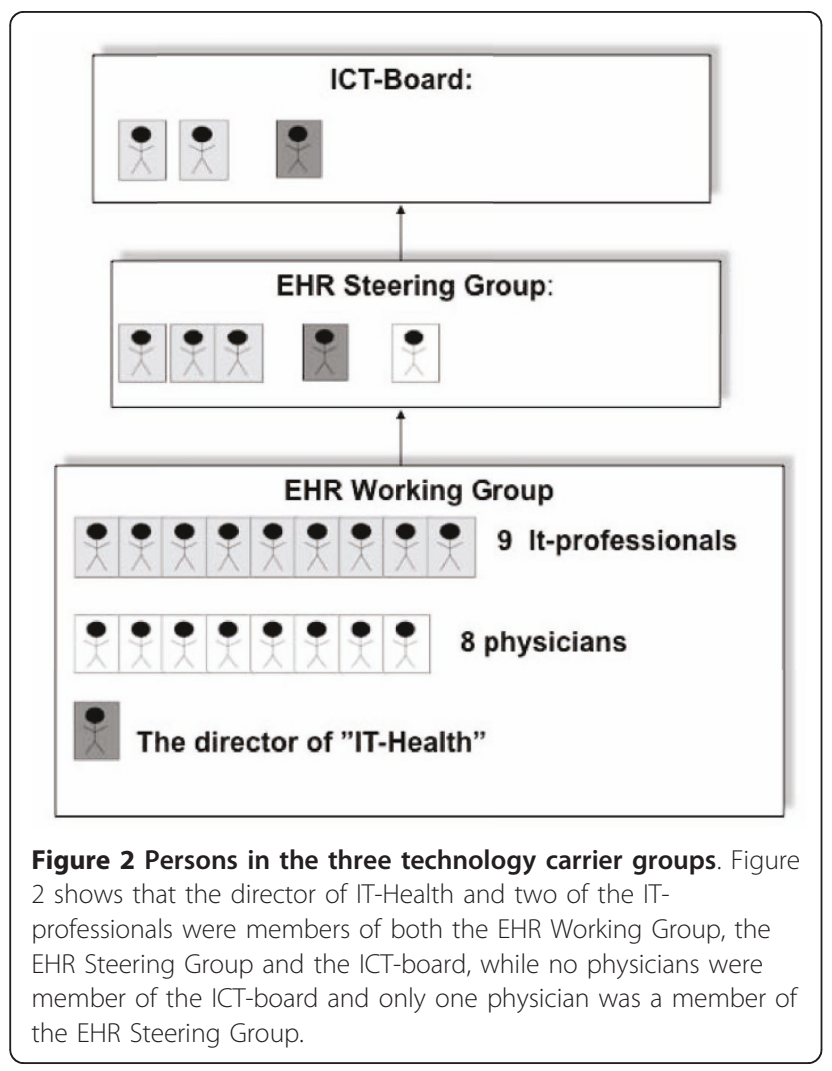

systems). Recognizing this problem, the physicians were offered to test four prototypes. None of the physicians were able to participate in all four tests because of clinical duties (no workload reduction), which meant that they were unable to compare the four systems. Thus, the tests did not provide the physician with a better basis for choosing between the systems. The fact that the four EHR systems could not be tested in a real live setting meant that clinical knowledge was not enough to chose between the systems. Technical knowledge became essential (see the knowledge aspect).

\section{Information}

The members of the working group, who were involved from the start, were invited to different arrangements as preparation for the different tasks they were asked to perform. The six physicians, who joined the working group 18 months after it was established, did not receive any kind of introduction or update on the work conducted so far - or any other kind of preparation for the task. This fact together with the fact that clinical workload reduction was not possibly - meaning that the physicians had their full-time clinical work beside the work in the EHR-working group - made it impossible for the six last physician members of the group to obtain the level of information necessary to achieve real influence in decision-making.

\section{Knowledge}

Because the four systems became almost alike with respect to system functions re-lated to clinical work practices, these were given up as criteria for selection between systems. This meant that clinical knowledge became inadequate as a basis for choosing between systems - technical knowledge was essential. Only one of the eight physicians had the necessary technical knowledge for true participation in the often very technical debates in the working group. The old saying: "knowledge is power" proved to be very true. The reality was: the more technical knowledge - the more power. The lack of technical knowledge made the physicians incapable of exerting real influence on several important decisions made during the process - e.g. the final choice of EHR system.

\section{Synthesis of the technology carrier analysis}

The analysis showed absence of workload reduction as the main barrier to the physicians to achieve true involvement in the process, and it affected all six conditions - interest, power, organization, information, access and knowledge - required to obtain the status of actual social carriers of the EHR. The clinicians role in the process was reduced to clinical consultants informing about physicians needs in the requirement specifications and other documents. However, they were not able to fill this role completely due to lack of time. Therefore, this work was to a large extent handled by IT- 
professionals from "IT-Health". The answer to the first research question is that none of the conditions required in order to obtain the status of actual social carriers of the EHR were met for the physicians in the EHR working group. Their initial status as potential carriers of the EHR remained unchanged. The results of the technology carrier analysis are synthesized and visualized in table 3 .

Table 3 shows to which degree the conditions for becoming an actual social carrier of the EHR were fulfilled for the different social groups on a three point subjective scale. Three marks indicate full achievement.

\section{SCOT analysis}

\section{The technological object and the social groups}

The technological object was the health record - paperbased or electronic. The social groups comprised physicians and IT-professionals associated with the Danish hospital sector and hospital managers and EHR decision-makers at county/regional level.

\section{Meanings and technological frames ${ }^{6}$}

Danish physicians form an inhomogeneous group with respect to their opinion on both problems and solutions associated with the paper-based health record. Therefore they were divided into two groups by the researcher: "Clinical physicians" and "Early adopters". Throughout the history of the health record the two groups of physicians have had an internal struggle for the power and the right to define the purpose of the health record. Throughout history, the "Early adopters" have advocated for the introduction of new versions based on visions of future clinical benefits - primary (clinical work) as well as secondary (teaching and research). The "Clinical physicians" have tried to "arrest" this development, partly because they have felt no need for new versions, partly in order to "keep up" with daily clinical practice. However, in the long-term perspective the "Clinical physicians" have always had to accept new - increasingly standardized - versions of the health record.

In the short-term perspective, however, several examples show, that the "Clinical physicians" have succeeded in curbing the development for a time $[34,57,58]$. The two groups of physicians have, however, recently taken a common external position when it comes to the primary purpose of patient data due to a growing interest in the use of health data for secondary non-clinical purposes (management and governance) among administrators and IT-professionals. This primary purpose is clinical use in daily practice. Secondary clinical use - and other secondary purposes - must not compromise the primary use.

Besides the internal power struggle about the right to define the purpose of the health record, the Danish physicians have also faced an external struggle against administrators, which has taken place ever since the outset of the Danish health record approximately 150 years ago. Historically, administrators have shown a growing interest in health records, because better possibilities for extracting data for primary and secondary clinical purposes also meant better possibilities for extracting data for secondary non-clinical purposes. The development of the EHR was originally initiated by the "Early adopters" with the internal control of treatment quality as its objective. This has, over the years, been overtaken by administrators with external control of quality, efficiency and financing as its objective. At the same time, the argument about patient safety, which for many years was used solely by physicians as an argument for using patient data for clinical purposes, is now also used by administrators to legitimize the use of patient data for non-clinical purposes. In recent years, the "Early adopters" - and thus the medical profession have lost most of the influence on the development of the health record to the administrators, and the physicians' power and right to define the purpose of health records appears more diminished today than ever before.

\section{Synthesis of the SCOT analysis}

The SCOT analysis contributed to a deeper understanding of the underlying reasons for the physicians not to obtain the status of actual social carriers of the EHR by uncovering the different meanings attached to the health record by the different relevant social groups. The answer to the second research question is that the different meanings the three social groups attached to the EHR are rooted in an inherited balance of power between physicians and administrators specifically. Ever since the outset of the Danish patient record, clinicians and administrators have fought for the power and the right to define its purpose. So far, administrators have so far won this battle and seem to have a stronger position today than ever. This inherited battle of power was the major reason for the approach chosen for the planning process in the $\mathrm{CNJ}$. This battle is considered to be

Table 3 Presentation of the results of the technology-carrier analysis

\begin{tabular}{|c|c|c|c|c|c|c|}
\hline Social group & Interest & Power & Organization & Information & Access & Knowledge \\
\hline Physicians & $\nabla$ & $\square$ & $\square$ & $\square$ & - & $\square$ \\
\hline IT-professionals & चv & चতच & चতマ & 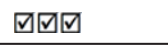 & - & चতच \\
\hline IT-board & ஏতవ & 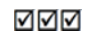 & অতত & $\square$ & - & $\nabla$ \\
\hline
\end{tabular}


the reason for the conditions made available to the EHR working-group by the ICT-board during the planning process; conditions that consequently reduced the role of physicians in the planning process in North Jutland to one of clinical consultants - rather than real participants.

\section{Discussion}

\section{Relating the method presented to other approaches}

While the method presented in this paper has been developed for the healthcare sector specifically and to cover the entire IT development process, most other methods for supporting and improving end-user participation in IT development have focused on the design stage [22] and/or have been developed for other organizations than the healthcare sector [22,25,29].

\section{Strengths and weaknesses of the study}

The purpose of this research was to develop an improved method to identify, study and understand end-user (physician) participation in HIT development in order to support and facilitate real end-user participation in HIT development. Well-known prerequisites for real end-user participation are early involvement ([22,23,30-32], representation $[25,28,33]$ and workload reduction $[25,26]$. The new approach presented in this paper have shed light on the interactions that occurred between the different social groups involved in the EHR planning process in the CNJ and have provided an understanding of the underlying reasons for these. Through a thorough examination of the six conditions necessary to require the status of an actual carrier of EHR (interest, power, organization, information, access and knowledge) the interac-tions between the social groups involved in the EHR planning process in the CNJ were disclosed, while the SCOT analysis shed light on the underlying reasons for this. However, these analyses also uncovered the prerequisites for real participation (early involvement, representation and workload reduction) and revealed that they were not met during the process.

On the basis of our findings we argue that the six conditions necessary to require the status of an actual carrier of EHR are good analytical markers for whether the preconditions for real participation are met or not in HIT development. Thus the method demonstrated has proven effective as a tool to support, facilitate and improve real end-user participation.

The present study is a qualitative study using triangulation of different data collecting methods to validate the data. The analytical framework supports and strengthens data analysis as it is based on an integration of well-known methods,

The method was developed throughout a research study in a major Danish healthcare organisation.
However, research shows that the interactions and the battle of power between different social groups are not specifically Danish phenomena, they can be found in HIT development in general [59]. Thus, we argue that a thorough study of the six conditions needed for the end-users to require the status of active carriers of a new technology, and thus for them to be real participants, will also in a broader context provide HIT management with valuable information on the social groups participating in HIT development and for the reasons for the variations.

The method was developed and used during the planning stage. However, we argue that it can be used at any stage as the importance of acquiring knowledge about and understanding the social interactions occurring between the social groups involved is equally important during all stages of HIT develoment.

For the method to be employed it is a precondition that management at all levels are actively supporting it throughout the process. This means that they must provide the resources necessary in terms of time and personnel, as the method could be rather time consuming, depending on which and how many emperically data collection-methods are used.

In qualitative studies there is a risk that the researcher has a predetermined opinion on the subject in question. It is also a risk that the researcher is "seduced" by the position taken by one group. To account for this, all activities throughout the process have been thoroughly described (transparency). The fact that one of the researchers $(\mathrm{AMH})$ has participated throughout the planning process in all meetings, and has had access to most documents - electronic as well as paper-based has made it possible to assess the truthfulness of, e.g. time pressure and the amount of documents related to the process.

\section{Conclusions}

Real end-user participation is essential for the successful outcome of HIT development - and thus for fulfilling the key objectives for healthcare. However, the interests of and the balance of power between the different social groups involved in HIT development are decisive for real end-user participation.

The method presented in this paper is a new, improved methodological approach which has proven effective for collecting more detailed information on end-users participation in HIT-development by disclosing the social interactions that occur between the social groups involved. Providing an understanding of the underlying reasons for the variations in the social groups participating by uncovering the different meanings attached to the HIT in question by the different relevant social groups has also proven effective. 
This improved method for disclosing and understanding the social interactions between social groups in HIT development provides an important tool for HIT project management at any level. It allows new avenues to be explored during the process in order to support, facilitate and improve real end-user participation.

\section{Endnotes}

${ }^{1}$ Jan.1. 2007, 13 Danish counties were merged into five regions

${ }^{2}$ A group of actors or a social entity, which chooses the new technology and carries it forward towards the next phase in the process.

${ }^{3}$ Significance, goals, interests, needs (a concept used in the SCOT theory).

${ }^{4}$ In the Social-carrier-of-Technology theory the concept "technology" means technique.

${ }^{5}$ Purpose, significance, goals, interests.

${ }^{6}$ Includes e.g. purposes, goals, problem-solving processes - historically and nowadays - for the different social groups.

\section{Acknowledgements}

We would like to thank the County of North Jutland for taking part in financing this project and thereby making it possible.

\section{Authors' contributions}

All of the authors contributed to the conceptual design of this study. AMH carried out the data collection, performed the analyses and was responsible for writing the manuscript. $\mathrm{PB}$ and $\mathrm{CN}$ were involved in drafting the manuscript and revising it critically for important intellectual content. All three authors have read and approved the final manuscript.

\section{Competing interests}

The authors declare that they have no competing interests.

Received: 16 March 2011 Accepted: 28 September 2011 Published: 28 September 2011

\section{References}

1. The Danish Ministry of Health: National strategi for IT i sygehusvæsnet 2000-2002. National strategy for IT in the hospital sector 2000-2002 København: Sundhedsstyrelsen; 1999.

2. The County of North Jutland: IT-Handlingsplan for sundhedsområdet $\mathrm{i}$ Nordjyllands Amt 2002-2004. IT-Plan for the healthcare area in the county of North Jutland 2002-2004 2000.

3. Berg M: Patient care information systems and health care work: a sociotechnical approach. International Journal of Medical Informatics 1999 87-101.

4. Lorenzi N, Riley RT: Organizational Aspects of Health Informatics. Springer Verlag; 1995

5. Lorenzi N, Riley RT, Blyth AJC, Southon G, Dixon BJ: Antecedents of the People and Organizational Aspects of Medical Informatics: Review of the Literature. Journal of American Medical Association 1997, 4.

6. Van der Meijden MJ, Tange H, Troost J, Hasman A: Development and implementation of an EPR: how to encourage the user. Int J Med Inf 2001, 64:173-85.

7. Kaplan B: Culture counts: How institutions values affect computer use. MD Comput 2000, 17:23-6.

8. Heeks RD, Mundy D, Salazar A: Why Health Care Information Systems Succeed or Fail: Information Systems for Public Sector Management. Manchester, UK: Institute for Development Policy and Management, University of Manchester 1999, Report No.: 9.
9. Southon G, Sauer c, Dampney K: Lessons form a failed information system initiative: issues for comples organisations. International Journal of Medical Informatics 1999, 55:33-46.

10. Vingtoft S, Lippert S, Bernstein K, Bruun-Rasmussen M, Kristensen M, Nøhr C: EPJ-Observatoriets Statusrapport 2000. EHR status report 20002000.

11. Wears RL, Berg M: Computer Technology and Clinical Work. Still Waiting for Godot. Journal of American Medical Association 2005, 293(10):1261-3.

12. Edmondson AC: Framing for Learning: Lessons in Successfull Technology Implementation. California Management Review 2003, 45(2):34-51.

13. Høstgaard AM, Nøhr C: Metodehåndbog i forandringsparathed i forbindelse med udvikling og implementering af nye it-systemer indenfor sundhedsvæsnet. Handbook in Methods for Change Readiness in development and implementation of new IT-systems in healthcare Aalborg, DK: Virtual Center for Health Informatics; 2004.

14. Ash J, Stavre Z, Kuperman GJ: A Consensus Statement on Considerations for a Successful CPOE Implementation. Journal of American Medical Association 2003, 10:229-34

15. Robertson A, Cresswell K, Takian A, Petrakaki D, Crowe S, Cornford T, Barber N, Avery A, Fernando B, Jacklin A, Prescott R, Klecun E, Paton J, Lichtner V, Quinn C, Ali M, Morrison Z, Jani Y, Waring J, Marsden K, Sheikh A: Implementation and adaption of nationwide electronic health records in secondary care in England: qualitative analysis of interim results from a pros-pective national evaluation. BioMedCentral 2010, 341(c4564)[http://www.biomedcentral.com], [cited 2010 Feb 12].

16. Berg M: Implementing information systems in health care organizations: myths and challenges. International Journal of Medical Informatics 2001, 64(2001):143-56.

17. Kaplan B, Harris-Salamone KK: Health IT Success and Failure: recommendations from Literature and an AMIA Workshop. J Am Med Inform Assoc 2009, 16(3):291-9.

18. Van der Meijden MJ, Tange H, Troost J, Hasman A: Determinants of Success of Inpatient Clinical Information Systems: A Literature Review. Journal of American Medical Association 2003, 10:235-43.

19. Kaye R, Kokia E, Shalev V, Idar D, Chinitz D: Barriers and success factors in health information technology: A practitioner's perspective. Journal of Management \& Marketing in Healthcare 2010, 3(2):163-75.

20. Maddock E: The benefits of implementing an elevtronic patient record system. Nursing Times 2002, 98(49):34-36[http://www.nursingtimes.net], [cited 2010 Mar 12].

21. Simonsen J, Hertzum J: A Regional PD Strategy for EPR Systems: Evidence-Based IT Development. Palo Alto, CA: CPSR; 2006, 125-8.

22. Bødker K, Kensing F, Simonsen J: Participatory IT Design. Designing for Business and Workplace Realities. MIT Press; 2004

23. Johnson CW: Why did that happen? Expooring the proliferation of barely usable software in healthcare systems. Quality and Safty in Health Care 2006, 15(supplement 1):i76-i81.

24. Pare G, Sicotte C, Jacques H: The Effects of Creating Psychological Ownership on Physicians' Acceptance of Clinical Information Systems. Journal of the American Medical Informatics Association 2006 13(2):197-205

25. Kensing F, Blomberg J: Participartory Design; Issues and concerns. Computer Supported Cooperative Work 1998, 7:167-85.

26. Høstgaard AM: Fryder forandring? Casestudie af EPJ udbudsprocessen i Region Nord - belyst gennem en procesevaluering med fokus på lægerne som sociale bærere af den elektroniske patientjournal, EPJ. Change is the spice of life?; process analysis case study of a region in Denmark, Ph.d. thesis Aalborg: Aalborg Universitet; 2009.

27. Kushniruk A, Turner P: Who's Users? Participation and Empowerment in Socio-Technical approaches to Health IT development. International Perspectives in Health Informatics 2011, 280-5.

28. Mumford E: Designing Human Systems for New Technology - The ETHICS Method. Manchester UK: Manchester Business Schol; 1983.

29. Mumford E, Weir M: Computer systems in work design: The ETHICS method. London: Associated Business Press; 1979.

30. Müller J, Kjær-Rasmussen J, Nøhr C: Proactive Technology Assessment as a Tool in HIS Development. In MEDINFO 1989. Edited by: Barber B, et al. Singapore.North Holland; 1989:

31. Lorentzen A: Teknologi og udvikling i den nordjyske maskinindustri. Technology and development in engineering in the norhtern part of Denmark Aalborg, DK: Aalborg Universitetsforlag; 1994. 
32. Protti D: What can the American electronic health record (EHR) pioneers tell us about what it takes to be successful? Health Management Forum 2002, 15(2):33-5.

33. Fitzgerald G: Effective Technical and human implementation of computer-based system (ETHICS). Information system development: Methodologies, Techniques and Tools.Berkshire UK: The McGraw-Hill Companies; 2006, 353-64

34. Scott JT, Rundall TG, Vogt TM, Hsu J: Kaiser permanente's experience of implementing an electronic medical record: a qualitative study. Information in practice 2005.

35. Nøhr C, Høstgaard AM, Botin L, Kjær-Andersen S: Evaluering af GEPKAprojektet, Delrapport 2, Klinisk afprøvning. Evaluation of the GEPKA-project, report 2, Clinical testing Aalborg University: Virtual Center of Health Informatics; 2004.

36. Nørh C, Høstgaard AM: Brugererfaringer fra GEPKA projektet på afdeling $\mathrm{M}$, Århus Sygehus. User experience from the GEPKA project in Århus hospital Aalborg University: Virtual Center for Health Informatics; 2005.

37. Shah SG, Robinson I: User involvement in healthcare technology development and assessment: structured literature review. Int I Health Care Qual Assur Inc Leaders Health Serv 2006, 19(6-7):500-15.

38. Shah SG, Farrow A, Robinson I: The representation of healthcare end users' perspectives by furrogates in healthcare decisions: a literature review. Scand J Caring Sci 2009, 23(4):809-19.

39. Money AG, Barnett J, Kuljis J, Craven MP, Martin JL, Young T: The role of the user within the medical device design and development process: medical device manufacturers' perspectives. BMC Med Inform Decis Mak 2011, 11(1).

40. Nies J, Pelayo S: From users Involvement to users' needs understanding: a case study. Int J Med Inform 2010, 79(4):76-82

41. Shah SG, Robinson I: Developing medical device technologies from users' perspectives: a theoretical framework for involving users in the development process. Int J Technol Assess Health Care 2009, 25(4):514-21.

42. Gregory J: Sorcerer's Apprentice: Creating the Electronic Health Record, Re-inventing Medical Records and Patient Care. University of San Diego, Califonia; 2000.

43. Müller J, Kjær-Rasmussen J, Nøhr C: Perspektiver for EDB-teknologi sygehusvæsenet. Perspectives for IT-technology in the hospital sector Aalborg: Institut for Samfundsudvikling og Planlægning, Aalborg Universitetscenter, Aalborg; 1988.

44. Kuanda J: Culture and Technological Transformation in the South. In Perspectives on Technological Transformation. Edited by: Müller J. Danmark, Samfundslitteratur Press; 2003:27-98

45. Müller J: Hvad er teknologi? (What is technology?). In Samfundet i teknologien. Edited by: Rostgaard M, Remmen A, Christensen J. Aalborg: Aalborg Universitetsforlag; 1991:27-47.

46. Edquist C, Edquist O: Social carriers of Techniques for Development. Journal of Peace Research 1979, 16(4):313-31.

47. Müller J: Teknologivurdering og troværdighed. (Technology assessment and credibility). In Metoder i teknologivurdering. Erfaring og fornyelse.. 8 edition. Edited by: Cronberg T, Friis D. København: Blytmanns forlag; 1990:267-79.

48. Nøhr C, Bernstein K: Implementation and Diffusion of Medical Informatics; The case of Electronic Prescription Communication. Between Practitioners and Pharmacies. Primary Health Care Specialist Group of the British Computer Society 1992, 14-8.

49. Bijker WE, Huges TP, Pinch T: The Social Construction of Technological Systems. Massachusetts: MIT Press; 1989.

50. Muhr T: ATLAS: The knowledge workbench. V5.0 User's Guide and Reference Berlin: ATLASti.Scientific Software Development GmbH; 2004

51. Jespersen H: Sygepleje og EPJ (Nursing and EHR). Århus, DK: Institut for Sygeplejevidenskab, Århus Universitet; 2004

52. Bruun Jensen C: En performativ historie: EJP som en fremtidsgenererende anordning. A performative history: EHR as a future-generating device 2006

53. Jacobsen $\mathrm{K}$, Larsen $\mathrm{K}$ : Ve og Velfærd; Læger, sundhed og samfund gennem 200 år. Woe and Welfare; Physicians, health and society during 200 years København: Linhart og Ringhof; 2007.

54. Bruun Jensen C, Lauritsen P, Olesen F: Introduktion til STS. Introduction to STS København: Hans Reitzels Forlag; 2007.
55. Brandt E: Designing Exploratory Design Games: A Framework for Participation in Participatory Design? Proceedings Participatory Design conference 2006.

56. Simonsen J, Hertzum J: Participative Design and the Challenges of LargeScale Systems: Estending the Itereative PD Approach. Proceedings Participatory Design conference 2008.

57. Bossen D, Krüger E, Weeke J: Rapport om afprøvning af Århus Amts G-EP prototype. Report on the testing of the G-EHR in the county of Arrhus Aarhus: Informations- og Medievidenskab, Aarhus Universitet; 2005.

58. Bossen C: Evaluation of a computerized problem-oriented medical record in a hospital department: Does it support daily clinical practice? International Journal of Medical Informatics 2007, 76:592-600.

59. Berg M, Winthereik BR: Waiting for Godot, Episodes from the history of patient records. In Health Information Management; Integrating Information Technology in health care work. Edited by: Berg M. London: Routledge: 2004:11-44.

\section{Pre-publication history}

The pre-publication history for this paper can be accessed here: http://www.biomedcentral.com/1472-6947/11/57/prepub

doi:10.1186/1472-6947-11-57

Cite this article as: Høstgaard et al:: Methods to identify, study and understand End-user participation in HIT development. BMC Medical Informatics and Decision Making 2011 11:57.

\section{Submit your next manuscript to BioMed Central and take full advantage of:}

- Convenient online submission

- Thorough peer review

- No space constraints or color figure charges

- Immediate publication on acceptance

- Inclusion in PubMed, CAS, Scopus and Google Scholar

- Research which is freely available for redistribution

Submit your manuscript at www.biomedcentral.com/submit
Ciomed Central 